\title{
Mobile Application Development for Improving Auditory Memory Skills of Children with Hearing Impairment
}

\author{
Youngmee Lee \\ Department of Communication Disorders, Tongmyong University, Busan, Korea \\ 청각장애 아동의 청각기억 향상을 위한 모바일 어플리케이션 개발 \\ 이 영 미 \\ 동명대학교 언어치료학과
}

\begin{abstract}
Purpose: As technological progress of the smartphones has been accelerating, the needs of applications (apps) for children with hearing impairment (HI) have been also increasing now in auditory habilitationists and their parents. This study introduces the process of developing the mobile apps for improving auditory memory skills of children with HI. Methods: The contents of the apps were developed based the professional knowledge and clinical experiences by the auditory habilitationists. The design model for developing the apps was proposed by the experts of the auditory habilitation and computer sciences. The usability testing was conducted to improve the apps' functions. Results: Six mobile apps were developed through the app-development process including planning, design, and programming. The results of the usability test showed that the apps were suitable and efficient to improve auditory memory skills for children with HI. Conclusion: The mobile apps developed in this study could be useful for improving auditory skills of children with HI in the clinical and home-based setting. This paper provides the process, knowledge, and experiences on developing the mobile app for auditory habilitation of children with $\mathrm{HI}$.
\end{abstract}

Key Words: Mobile application, Aural rehabilitation, Hearing impairment, Children, Auditory memory skills.

Received: December 14, 2016 / Revised: December 31, 2016 / Accepted: January 6, 2017

Correspondence: Youngmee Lee, Department of Communication Disorders, Tongmyong University, 428 Sinseon-ro, Nam-gu, Busan 48520, Korea Tel: +82-51-629-2135 / Fax: +82-51-629-2019 / E-mail: ymlee3060@gmail.com

\section{INTRODUCTION}

스마트 기기의 등장은 우리 사회를 스마트 미디어 사회로 변 화시켰으며, 스마트 기기 중에서 스마트폰의 성능과 기능은 이 동 및 정보 통신사업의 발전과 함께 짧은 시간 안에 비약적으 로 발전하였다(Jang \& Kim, 2010). 스마트폰이 등장한 초기에 는 비싼 기기 가격과 통신 비용으로 보급이 저조하였으나, 점차 스마트폰의 보급률이 높아져서 2015년에는 휴대폰 가입자 5,720 만명 중에서 약 $70 \%$ 가 스마트폰 사용자로 보고되었다 (Yoo, 2015). 모바일 시장조사업체인 와이즈앱이 10대에서 50대 까지의 국내 한국인 중에서 안드로이드 스마트폰 사용자 $(\mathrm{n}=$ 14,439)를 대상으로 스마트폰 사용 실태조사를 한 결과, 스마트 폰을 하루 평균 3 시간을 사용하고 있는 것으로 나타났다. 즉,
한국인의 하루 수면시간인 약 7시간을 제외하면, 스마트폰을 하루 활동 시간의 $25 \%$ 정도 사용하고 있었다(Mang, 2016). 그 리고 국내 스마트폰 사용자는 한 달에 평균 45 개의 어플리케이 션(application, 앱)을 사용하고 있어서, 스마트폰 사용 시간뿐 만 아니라 사용하는 앱 개수도 아시아-태평양 지역에서 가장 높은 수치였다.

스마트폰은 전화 통화와 메시지를 주고 받는 기존의 휴대폰 기능에 그치지 않고, 다양한 앱을 통해 일상생활에서의 정보 활용, 쇼핑, 금융, 여가 활동, 게임, 학습 등으로 일상생활에 영 향을 미치고 있다. 최근 들어, 성인, 청소년, 아동이 스마트 기기 에서 실행되는 앱을 이용하여 학습할 수 있는 모바일 러닝 (mobile learning)에 대한 관심이 높아지고 있다. 특히, 교육공 학 전문가들은 인터넷 접속이 가능하고 학습자 중심의 인터페 
이스를 제공할 수 있는 스마트폰을 활용한 모바일 러닝이 컴퓨 터를 이용하는 보조학습, $\mathrm{e}^{-}$러닝보다 활용도가 높아질 것으로 예상하고 있다(Lim \& Park, 2012). 모바일 러닝은 일반인에게 만 한정되지 않고 장애인을 대상으로도 확장되고 있으며, 국내 외에서는 장애 아동 및 성인의 일상생활, 말-언어 학습, 의사소 통 등에 도움을 주고 다양한 앱이 개발되어 출시되고 있다. 그 리고 앱 개발이 의료와 재활 영역으로도 확장되어, 질병의 진 단, 치료 가이드라인 제시, 치료 정보 제공, 자기 치료, 원격재활 (tele-rehabilitation) 등에도 활용되고 있다(Im et al., 2013).

의사소통장애(communication disorders)는 청각장애, 지체 장애, 지적장애, 자폐스펙트럼장애 등의 여러 가지 원인으로 발 생되며, 의사소통장애 발생시 타인과의 의사소통에 어려움이 초래된다. 청각장애는 의사소통장애를 일으키는 다른 장애 영 역과 달리 신생아청각선별검사를 통해 생후 2 3개월 안에 조 기 진단될 수 있다. 따라서, 조기 보청기 착용 및 조기 청능재활 (auditory rehabilitation)을 실시하여 말-언어 발달의 결정적 시 기(critical period) 동안 적절한 청각, 언어 자극을 제공함으로 써 청각장애 아동의 구어 의사소통 능력을 발달시킬 수 있다 (Cole \& Flexer, 2011). 하지만 청각장애 아동은 청각박탈(auditory deprivation)을 일정 시기 동안 경험하며, 보청기 및 인 공와우를 통해 들어오는 제한적인 청각정보로 말-언어 발달을 해야 하므로, 원활하고 자연스러운 구어 의사소통이 어려울 수 도 있다. 이러한 이유로 청능재활에서는 청각장애 아동의 잔존 청력(residual hearing)을 최대한 활용하여 청력 손실로 인해 발생될 수 있는 말, 언어 문제를 최소화하고, 궁극적으로 일상 생활에서 적절한 의사소통을 할 수 있도록 집중적으로 진행하 는 것이다(ASHA, 2016; Lee, 2008; Lee, 2016). Sweetow \& Sabes(2006)는 듣기 기술(listening skill)이 말소리를 지각하는 수동적인 기능이 아니라 의도와 집중을 요구하는 인지 활동이 라는 것을 강조하면서, 청능재활을 통해 듣기 기술의 발달이 잘 이루어져야 상대방의 말을 잘 이해하고 대화를 원활히 할 수 있 다고 언급하였다.

청능재활에서는 아동의 청능 발달 단계를 탐지(detection/ awareness), 변별(discrimination), 확인(identification), 이해 (comprehension)의 네 가지 단계로 나누고 있지만(Tye-Murray, 2009), 실제 재활 회기에서는 단계마다 구체적이고 세부적 인 목표를 설정하여 진행하여야 적절한 듣기 기술이 발달될 수 있기 때문에, 대상자의 연령, 청력손실 정도, 청각적 수행력, 중 복장애 유무 등을 고려하여 자극 조건(stimulus condition), 자 극 단위(stimulus units), 반응 양식(response formats) 등 조정 하여 난이도를 설정하고 연령과 발달에 적절한 다양한 활동을 구성한다. 청각장애 손실 정도가 비슷하더라도 청각장애인의 듣기 기술에 개인 간 차이가 나타나는 것은 청각통합기술의 발
달에 차이가 있기 때문이며, 이러한 청각통합능력을 향상시키 기 위해서는 청각 처리(auditory processing), 청각 기억(auditory memory), 청각 종결하기(auditory closure), 화용 기술(pragmatic skills), 의미 및 구문(semantics and grammatical shape), 메타 언어(meta-linguistics) 등에 대한 중재도 필요하다(Sweetow \& Sabes, 2006). 이렇듯 청능재활은 대상자의 특성에 따라 서 단계적이고 체계적으로 이루어져야 하며, 청각장애 아동의 경우에는 듣기 기술뿐만 아니라 말, 언어 발달까지 목표를 두고 진행하여야 한다.

청각장애 아동과 부모는 청능재활기관에 주 1 2회 방문하여 40 90분 동안 듣기 기술, 말, 언어, 의사소통, 부모와의 상호작 용 등과 관련된 활동에 참여하게 된다. 기존에 오프라인 형태 로 진행되는 청능재활을 모바일 러닝 형태로 가정에서도 제공 된다면, 청각장애 아동의 반복학습을 촉진하여 청능재활 효과 를 더 높일 수 있을 것이다. 다양한 콘텐츠를 그림, 글자, 음성, 동영상, 애니메이션 등으로 스마트폰에서 구현이 가능하기 때 문에, 스마트폰은 청각장애 아동이 흥미를 가지고 청능훈련에 참여하는 데 도구적으로 이용될 수 있다(Lee et al., 2015a; Lee, 2016). 이러한 긍정적인 효과를 기대하고 청능재활에서도 모바 일 러닝에 주목하기 시작하였으며, Yu et al.(2014)은 중도의 감 각신경성 성인에게 스마트폰 앱을 이용한 청능훈련을 실시하여 어음인지가 향상된 사례에 대해서 보고하기도 하였다. 그리고 Hwang \& So(2016)는 청각장애 아동의 교육용 앱은 인간중심 디자인 방법론을 적용하여 보편적 설계의 관점에서 앱을 개발 해야 된다고 언급하면서 '한글 말하기 듣기 학습 앱'의 개발과 정에 대해서 소개하기도 하였다.

선행 연구(Cheon \& Yim, 2016; Jeong, 2014; Lee \& Lee, 2016)에서 자폐스펙트럼장애, 뇌성마비, 청각장애 아동 등의 장 애 영역에서 앱을 활용한 중재의 긍정적인 보고가 임상 현장에 서 스마트폰, 다양한 앱, 스마트미디어 매체를 활용하는 등으로 청능재활의 접근방법을 다변화하는 데 영향을 미칠 것으로 보 인다. 그리고 Lee(2016)의 인공와우 아동의 부모를 대상으로 한 청능재활을 위한 앱 개발의 필요성과 요구도에 대한 설문조 사에서 상당수의 부모는 자녀의 스마트 기기 사용에 허용적이 었으며 다양한 연령대(영유아, 취학전기, 학령기)에서 모두 청 각-언어 기술에 대한 청능재활 콘텐츠에 대한 요구도가 높았 다. 특히, 청각장애 아동의 통합적인 듣기 기술을 향상시키기 위 해서 아동이 들은 청각정보를 차례대로 회상하는 청각기억 (auditory memory) 발달이 중요하며, 이는 연결발화(connected speech) 이상의 수준에서 상대방의 메시지를 이해하는 데 필수 적이다(Jutras et al., 2003). 청능재활 전문가가 청각기억 발달 을 촉진하기 위해서 구조화된 놀이 상황에서의 반복훈련(play drill)을 청각장애 아동에게 실시하기도 하며, 이 과정에서 청각 
장애 아동은 반복되는 활동에 지루해하거나 힘들어하기도 한 다. 이에 따라서 본고에서는 변화된 스마트 환경과 청능재활 요 구를 충족하고자 청각장애 아동이 흥미를 가지고 청각기억을 향상시키는 활동에 참여할 수 있는 안드로이드 기반의 앱을 개 발하였으며, 앱의 기획과 개발 과정을 소개하고자 한다.

\section{MATERIALS AND METHODS}

\section{콘텐츠 조사 및 준비 단계}

콘텐츠 조사를 위해서 현재 압도적으로 높은 앱 점유율을 차지하고 있는 구글 플레이 스토어(Google play)와 앱 스토어 (App store)의 공식 웹 사이트를 통해서 청각장애 관련 앱을 조사하였다. 국외에서 개발된 앱은 언어의 차이로 인해서 청각 장애 아동 및 성인이 청능재활에 활용하기가 어렵기 때문에, 국내 앱 시장을 중심으로 앱을 검색하였다. 앱 시장에는 '청능 재활'에 대한 카테고리 등록이 되어 있지 않기 때문에, '청각장 애', '청각재활', '청능재활' 용어를 사용하여 앱을 검색하였다. 그 결과, 수화 번역 및 학습, 음성 산출, 한글 학습 등의 앱이 출
시되어 있었으며, 청각장애 아동을 위한 앱은 한글 교육과 환 경 소음 제공을 위한 앱이 있었다.

청각장애 관련 앱은 수화를 번역하거나 문자를 음성으로 전 환해주는 의사소통 도구형 앱이 많았으며, 학습을 목적으로 하는 앱에는 수화나 한글을 익히는 앱이 있었다. 환경소음을 제시하여 청능재활에 도움을 주는 앱이 있었지만, 청각장애 아 동과 성인의 듣기 기술 향상을 위한 콘텐츠가 포함되어 있지는 않았다. 국내에 출시된 앱을 살펴보면 청능재활의 목표를 달성 하기 위한 전문적인 콘텐츠를 갖추고 있지 않았으며, 청각장애 아동의 듣기 기술 향상을 위해서 개발된 앱 수도 미비한 수준 이었다. 따라서 청각장애 아동의 듣기 기술을 향상시킬 수 있는 청각기억 증진 콘텐츠와 아동이 쉽고 재미있게 조작할 수 있는 청각기억 앱 개발의 필요성을 파악하였다.

\section{기획 및 개발 단계}

\section{시나리오 설계}

청각장애 아동이 콘텐츠와 자연스럽게 상호작용하면서 앱

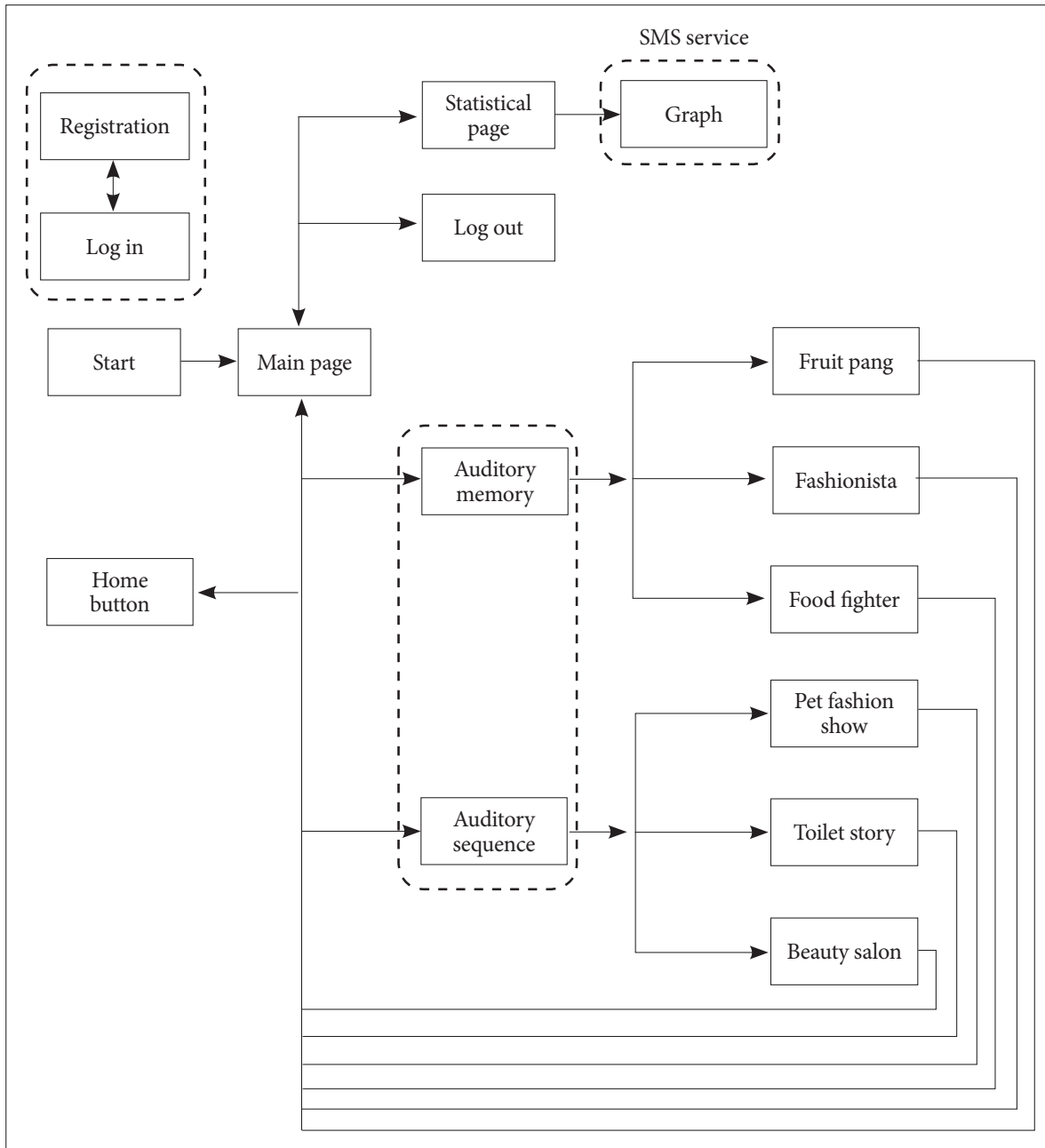

Figure 1. Flow of the application's scenario. 
활동에 참여할 수 있게 아동의 흥미를 고려한 시나리오로 설계 하였으며, 앱 시나리오는 과일 주스 만들기, 옷 입기, 음식 주문 하기, 강아지 꾸미기, 화장실, 미용실과 같이 총 6 개의 에피소드 로 구성하였다. 앱 시나리오의 흐름도는 Figure 1 에 제시하였다.

Yoo et al.(2012b)은 아동용 교육 콘텐츠에서는 '캐릭터'라는 요소가 아동이 학습의 목적과 목표에 가까워질 수 있도록 연결 해주는 역할을 하고, 시각적으로도 아동에게 즐거움과 호기심 을 주는 역할을 할 수 있다고 하였다. 본 앱의 개발에서도 캐릭 터가 청각장애 아동의 학습을 촉진하고 흥미를 유지하는 데 중 요한 요소가 될 수 있기 때문에, 6 개의 에피소드에는 아동에게 친근한 캐릭터가 등장하고 단어와 발화를 듣고 스마트폰의 조 작을 자연스럽게 유도할 수 있도록 시나리오를 설계하였다 (Figure 2).

\section{앱 구현 기능 작성}

앱에서 구현할 상세 기능은 앱 조작과 관련된 주요 기능과 직접적인 기능을 하지는 않지만 유기적으로 연동되어야 하는 부가 기능에 대해서 정리하였다. 앱에 필요한 기능에 대한 사전

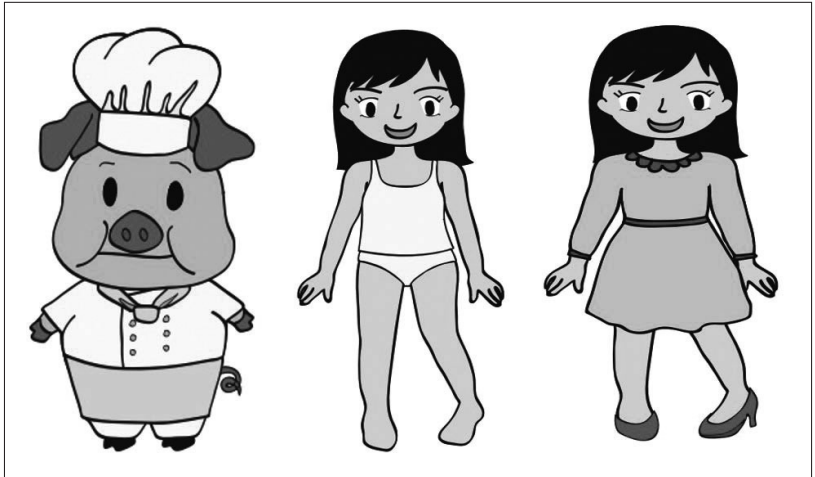

Figure 2. Examples of the application's characters.
조사를 하기 위해서, 청능재활 분야에서 3년 이상의 임상 경력 을 가지고 있으면서 석사학위 이상을 소지한 청능재활 전문가 3 인에게 포커스 그룹 인터뷰를 실시하였다. 포커스 그룹 인터뷰 결과를 참조하여 앱에서 구현할 주요 기능에는 목표 단어와 발 화의 정확한 음성 제시, 아동의 정오반응에 대한 피드백 기능 을 확인하였으며, 부가 기능에는 전문가와 부모 간 아동 정보 공유, 아동 수행 이력 저장 및 조회, 수행력의 추이를 그래프로 제시, 수행 이력을 SMS 서비스 기능을 사용하여 내보내기 기 능을 확인하여 결정하였다.

\section{절차도 작성}

앱 개발 시에 일어날 수 있는 불필요한 작업이나 중복된 절차 가 발생되지 않도록 Figure 3 과 같은 절차도를 작성하였다. 절 차도 개발을 위해 파워포인트로 레이아웃을 제작하여 앱 개발 자와 여러 차례 회의를 하였으며, 절차도 개발 시 앱 실행 과정 이 청능재활 임상에서 이루어지는 말소리 제시, 아동의 반응, 반응에 대한 정오 피드백이 원활하게 이루어지게 하는 데 초점 을 맞추었다. 절차도를 통해서 앱 구조를 확정지었으며, 레이아 웃과 절차도를 통해서 앱 전체의 구조 파악, 페이지 간의 이동, 페이지의 구성 등과 같은 내용을 확인하였다.

\section{어휘 목록 개발}

본 연구에서 개발할 앱은 취학 전의 말, 언어 발달이 단계에 있는 청각장애 아동의 청각기억을 향상시키기 위한 것이므로, 청각장애 아동에게 제시할 단어는 발달연령, 친숙도, 빈도를 고 려하여 어휘를 선정하고자 하였다. 취학 전 아동의 자발화에서 고빈도 어휘를 수집한 Choi(2000)와 Choi(2004)의 자료, 국립 국어교육원(Korean Institute of Korean Language, 2012) 자 료 중에서 두 개 이상의 목록에서 공통적으로 나타난 538개

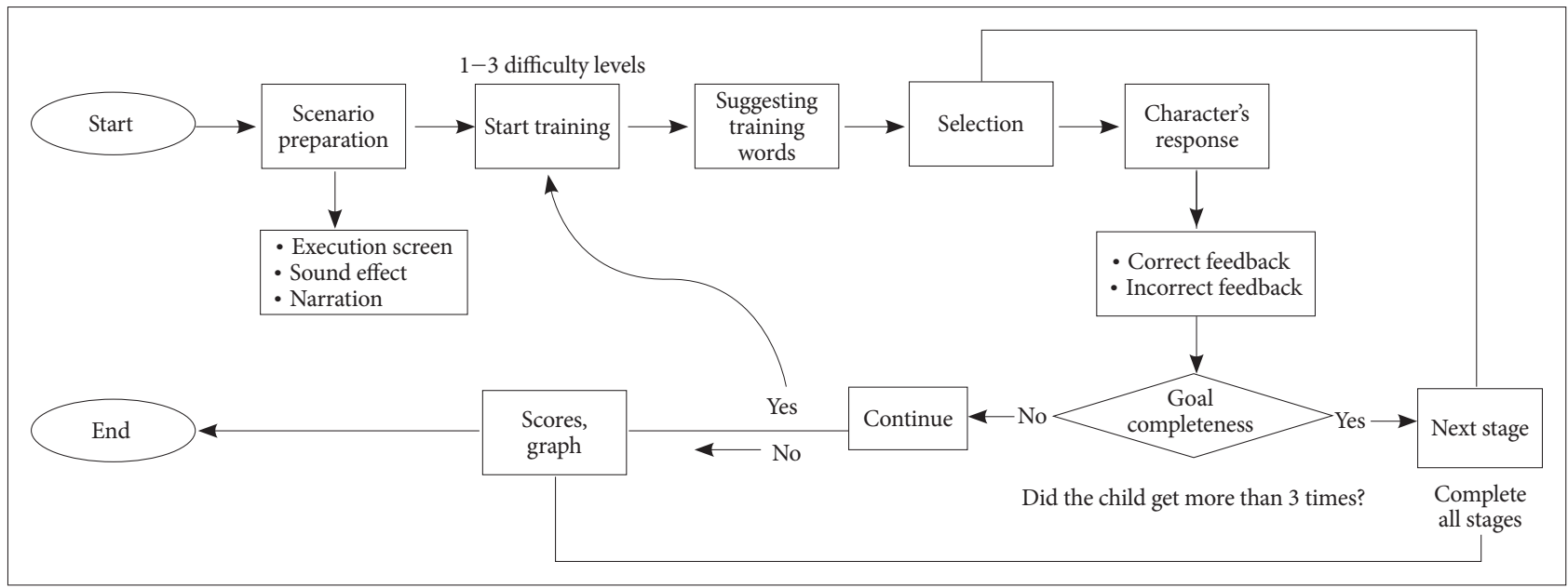

Figure 3. Framework for developing the application. 
어휘를 추출하여 1 차 어휘 목록을 마련하였다. 추출된 어휘에 대한 친숙도 점검은 유치원 교사에 의해 정상적인 말-언어 발 달을 하고 있다고 보고된 3 5세 건청 아동을 자녀로 둔 어머니 5명을 대상으로 어휘에 대해서 5점 Likert 척도(1점: 매우 친숙 하지 않음, 2점: 친숙하지 않음, 3점: 보통, 4점: 친숙함, 5점: 매 우 친숙함)를 이용하여 평정을 진행하였다. 그리고 언어치료 임 상경력이 5년 이상, 언어재활사 1급 자격증을 소지한 3 인에게 해당 어휘가 교육용으로 적절한지에 대한 타당도를 5점 Likert 척도(1점: 매우 적절하지 않음, 2점: 적절하지 않음, 3점: 보통, 4 점: 적절함, 5점: 매우 적절함)로 평정하였다. 최종 어휘 목록에 는 평균 4점 이상으로 평정된 503개의 어휘가 포함되었으며, 시 나리오와의 적절성을 기준으로 최종 어휘 목록에서 시나리오 스토리 활동과 적절한 어휘만으로 142 개를 선정하였다.

\section{음원 녹음 및 효과음 작업}

청각장애 아동의 청각기억 향상을 위해서 개발되는 앱이므 로, 목표 단어와 발화를 청각장애 아동이 명료하게 들을 수 있 어야 하며, 앱과 상호작용을 할 수 있도록 유도하는 나래이션 이 필요했다. 이를 위해서 앱의 캐릭터가 아동에게 말을 건네고, 목표 단어를 음성으로 제시하고, 아동의 정오반응에 대한 피드 백을 정확하게 전달할 수 있도록 효과음 작업을 진행하였다. 먼 저, 캐릭터의 사실성을 높이고 명료한 음성을 녹음하기 위해서 전문 배우(여성)를 섭외하여 스튜디오에서 녹음하였으며, 녹음 된 음성이 취학 전 청각장애 아동에게 들려주기에 적절한지 음 성 타당도를 진행하였다. 음성 타당도 점검은 언어재활사 2 인에 게 녹음된 음성의 발음, 음도, 속도 측면에서 5점 Likert 척도(1 점: 매우 적절하지 않음, 2점: 적절하지 않음, 3점: 보통, 4점: 적 절함, 5 점: 매우 적절함)로 평가하도록 하였다. 그 결과, 청각장애 아동이 녹음된 음성을 듣기에 발음, 음도, 말 속도 측면에서 4.85점 이상으로 적절한 것으로 평가되었다. 또한, 앱에서 등장 하는 캐릭터의 움직임, 아동의 정오반응에 대한 피드백에 대해 서 흥미를 높이기 위해서 적절한 효과음을 선정하였다.

\section{앱 구현}

국내외 스마트폰은 안드로이드 OS와 iOS 기반의 플랫폼이 주류를 이루고 있으며, 국내 스마트폰의 OS는 구글 안드로이 드 사용자가 $76.7 \%$ 를 차지하고 있어서 월등히 높은 편이다 (Kim, 2016). 이러한 이유로 앱을 안드로이드 OS 기반으로 개 발하였으며, 앱의 개발 환경 및 실행 환경은 Table 1 과 같다.

앱의 상호작용성(interactivity), 학습용이성(learnability), 기 억용이성(memorability)을 향상시키기 위해서 UI를 설계하였 다(Lee, 2012). 앱 개발 초기 단계부터 디자이너를 섭외하여 지 속적인 회의를 거쳐서 캐릭터를 디자인하고 목표 단어를 이미
지화하는 작업을 진행하였으며(Figure 2, 4), 이미지 작업 후반 부에는 앱 구현에 필요한 아이콘, 점수 이력 제시 등과 같은 사 이드 이미지 작업도 진행하였다. 이미지 작업 후에는 유치원 교 사 5 인과 취학 전의 건청 아동 10 명을 대상으로 그림 타당도 작 업을 거쳐서 혼동의 여지가 있는 그림에 대해서는 수정, 보완하 였다. 청각장애 아동의 반응을 유도하기 위해서 캐릭터의 표정 이 변화되기도 하며, 아동의 정오반응에 대한 피드백을 웃거나 우는 표정 등을 보여주는 식으로 하여 역동적인 상호작용을 유도할 수 있도록 하였다(Figure 5).

\section{사용성 평가}

앱 개발이 완료되기 전에 앱 시험판을 평가하여 앱 실행상의 오류 발견과 사용자 입장에서 개선사항이 있는지를 파악하기 위해서, 전문가(언어재활사와 청능사) 15 명을 대상으로 사용성 평가를 하였다. 사용성 평가에 참여한 대상자의 구체적인 정보 는 Table 2와 같다. 대상자의 연령대는 20대 5명(33.3\%), 30대 6

Table 1. Development environments for implementing the application

\begin{tabular}{ll}
\hline \multicolumn{1}{c}{ Items } & \multicolumn{1}{c}{ Environments } \\
\hline OS & PC (Windows 7 ultimate K) \\
ASD kit & Android 5.0.1 \\
AND kit & Android-ndk-r11c \\
Java development kit & Java SE 8u31 \\
Test device & SM-N900S (Samsung galaxy S4) \\
\hline
\end{tabular}

ASD: Android software development, AND: Android Native Development

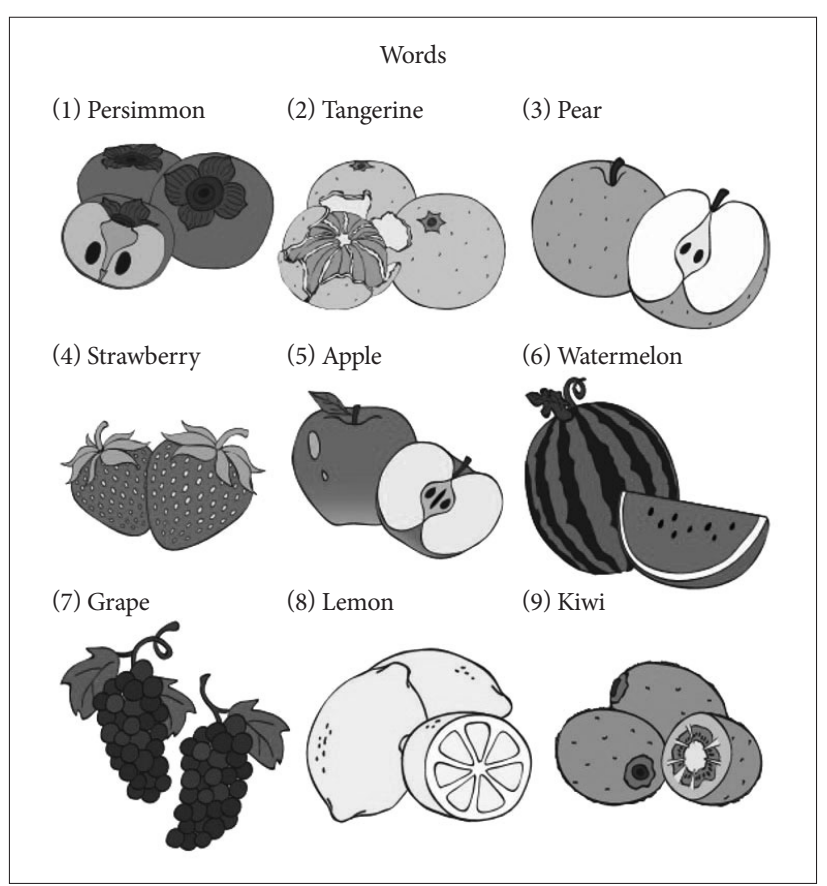

Figure 4. Image work of target works. 


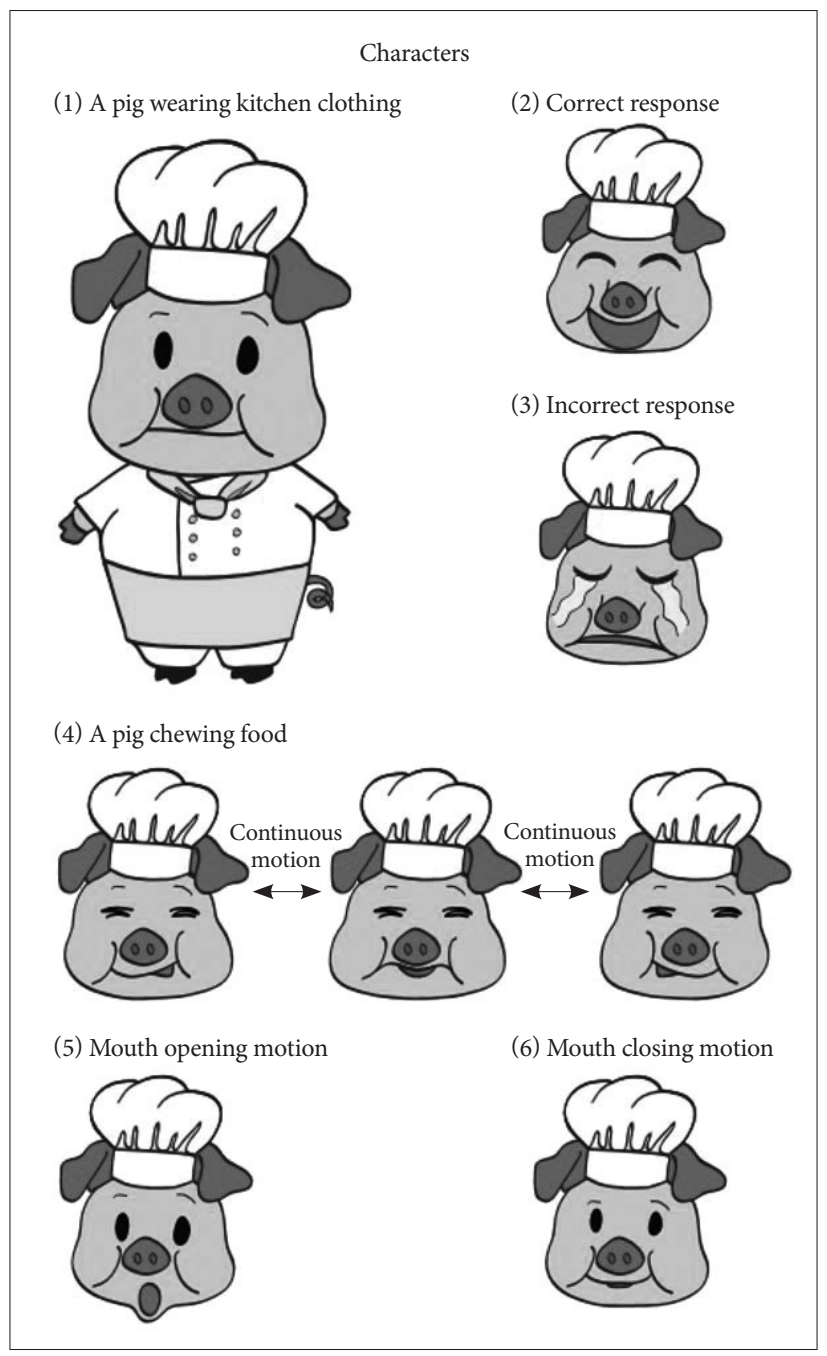

Figure 5. Examples of the character's images.

Table 2. Participants' information

\begin{tabular}{lc}
\hline \multicolumn{1}{c}{ Classification } & Frequency $(\%)$ \\
\hline Age $(\mathrm{yr})$ & $5(33.3)$ \\
$20-29$ & $6(40.0)$ \\
$30-39$ & $3(20.0)$ \\
$40-49$ & $1(6.7)$ \\
$50-59$ & \\
Education degree & $2(13.3)$ \\
Bachelor & $10(66.7)$ \\
Master & $3(20.0)$ \\
Ph.D. & \\
Working experience (yr) & $1(6.6)$ \\
$<1$ & $3(20.0)$ \\
$1-3$ & $3(20.0)$ \\
$3-5$ & $3(20.0)$ \\
$5-7$ & $3(20.0)$ \\
$7-9$ & $2(13.3)$ \\
$>9$ &
\end{tabular}

명 $(40 \%), 40$ 대 3 명 $(20 \%), 50$ 대 1 명 $(6.7 \%)$ 이었다. 대상자의 학력 은 학사 2명(13.3\%), 석사 10명(66.7\%), 박사 3명(20\%)이었으며, 임상 경력은 1년 이내가 1명(6.6\%), 1 3년이 3명(20\%), 3 5년이 3명(20\%), 5 7년이 3명(20\%), 7 9년이 3명(20\%), 9년 이상은 2 명(13.3\%)이었다.

사용성 평가는 앱에 대한 오리엔테이션, 앱에 대한 직접 조 작 및 체험, 설문지 평가(평가자 배경 정보, 앱 평가) 절차로 이 루어졌으며, 사용성 평가 설문지는 앱의 기능성(30문항)과 참여 자의 기본 정보(10문항)를 묻는 총 40 문항으로 구성하였다. 선 행 연구(Hyun et al., 2013; Jang et al., 2012; Lee et al., 2015a; Yoo, 2006; Yoo et al., 2012)를 참조하여, 앱의 적절성(5문항), 상호작용성(5문항), 유희성(5문항), 용이성(5문항), 편재성(5문 항), 교육효과성(5문항)의 여섯 영역으로 설문 문항을 개발하였 다. 여기서 편재성(ubiquity)은 장소, 시간에 구애 받지 않고 앱 을 이용할 수 있는 정도와 관련된 것으로, 시간 제약, 장소 제 약, 즉각성, 편리성, 시작과 종료에 관한 5 개의 문항으로 구성하 였다. 설문 문항의 반응은 '전혀 그렇지 않다(1점)'에서 '매우 그 렇다(5점)'까지 5점 Likert 척도를 이용하여 표시하도록 하였 다. 앱 개발에 참여해본 경험이 있는 전문가 2 인에게 설문 문항 에 대한 내용 타당성과 문장 적절성에 대한 검증을 받았으며, 중복되거나 부적절한 문항에 대해서 수정하여 총 30 개의 문항 으로 구성된 사용성 평가 설문 문항을 완성하였다. 설문 문항 의 일부를 Appendix에 제시하였다.

\section{RESULTS}

\section{앱 개발}

앱은 주요 기능과 부가 기능을 구현하였으며, 이에 따라서 크게 두 가지 모듈로 나누어진다. 주요 기능 모듈에는 청각기억 향상을 위한 6 개의 시나리오가 아동의 수행에 따라 3 단계 난 이도로 실행되며, 부가 기능 모듈에는 정보 입력, 신규 등록/로 그인, 점수 이력을 확인하고 전문가에서 수행 결과를 $\mathrm{SMS}$ 로 전송할 수 있도록 하였다.

부모가 청각장애 아동의 정보를 입력하여 신규 등록과 로그 인을 하면, 세부 시나리오를 선택할 수 있는 메인 화면이 실행 된다(Figure 6). 이때, 아동이 단어를 듣고 기억하는 앱(3종)과 문장을 듣고 순서화하는 앱(3종)의 아이콘을 선택하면, 해당 시나리오의 앱이 실행된다(Figure 7). 단어를 듣고 기억하는 앱 의 경우, 아동이 나래이션으로 제시되는 단어(예, "사과", "사과, 딸기", “사과, 딸기, 포도” 등)를 1개에서 3개까지 듣고 해당 이미 지를 차례대로 클릭 혹은 드래그하여야 하는 것으로, 난이도는 기억해야 하는 단어 개수에 따라서 1 단계(단어 1 개)에서 3 단계 (단어 3개)까지 조정된다. 문장을 듣고 순서화하는 앱의 경우, 


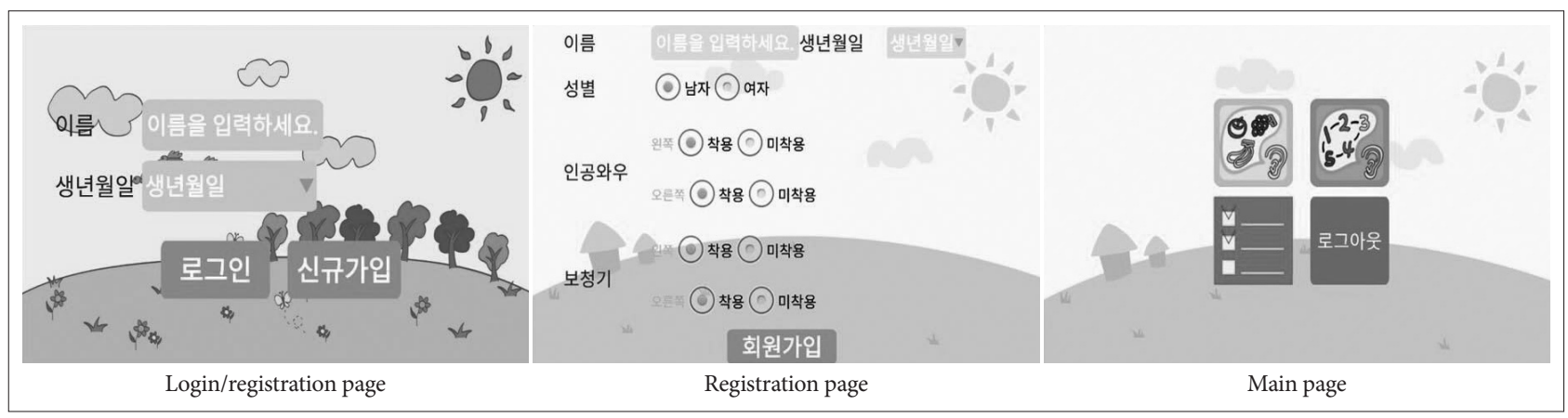

Figure 6. Execution page of the application.
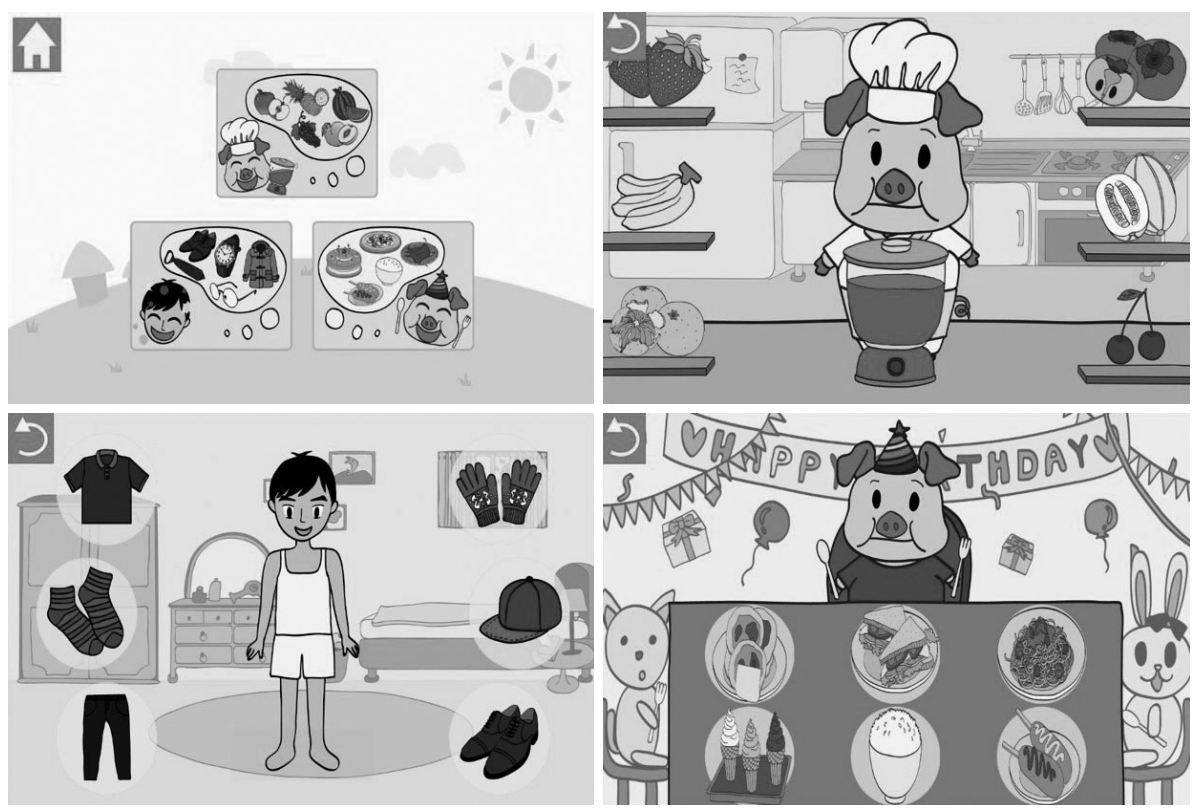

Figure 7. Examples of selecting the applications.

아동이 제시되는 문장(예, “손 씻어”, “손 씻고 이 닦아", “손 씻 고 이 닦고 목욕해" 등)을 듣고 핵심단어를 기억하여 해당되는 이미지를 차례대로 클릭 혹은 드래그해야 되며, 난이도는 동작 횟수(동작어 개수)에 따라서 1단계(1단계 지시 따르기)에서 3단 계(3단계 지시 따르기)까지로 조정된다. 이때, 아동의 수행에 따 라서 정반응(예, 웃는 얼굴과 웃음 소리)과 오반응(예, 우는 얼 굴과 울음 소리) 등이 제시되며, 연속해서 5 번 정반응을 보였을 때에는 자동적으로 다음 난이도의 단계로 이동한다(Figure 8). 앱 활동 종료 후에는 수행 점수 확인과 그 결과를 $\mathrm{SMS}$ 전송하 도록 하여, 부모가 전문가와 자녀의 수행 결과에 대해서 공유 할 수 있게 하였다(Figure 9).

\section{사용성 평가 결과}

참가자 $(\mathrm{n}=15)$ 에게 시험판을 조작하고 체험할 시간을 충분 히 준 다음, 앱의 사용성 평가를 5점 척도로 평정하는 설문 조 사로 실시하였다. 사용성 평가는 앱의 적절성, 상호작용성, 유 희성, 용이성, 편재성, 교육효과성의 6가지 영역에서 진행되었으
며, 각 영역에서의 평균은 적절성이 $4.28(\mathrm{SD}=0.50)$, 상호작용 성이 4.15(SD = 0.61), 유희성이 3.88(SD = 0.88), 용이성이 4.13 $(\mathrm{SD}=0.56)$, 편재성이 $4.68(\mathrm{SD}=0.56)$, 교육효과성이 $4.16(\mathrm{SD}$ = 0.79)으로 나타났다(Figure 10).

\section{앱 등록}

사용성 평가를 통해 앱 시험판의 오류나 불편 사항을 개선하 는 보완 작업을 하였으며, 앱 등록을 위한 절차를 진행하였다. 안드로이드 개발자 등록 사이트(http://play.google.com/apps/ publish)에 접속하여 수수료(25달러)를 지불하고 개발자 등록 을 하였다. 그 후, 앱 실행 파일을 안드로이드 마켓 페이지에 등 록하였으며, 마켓 등록 승인을 완료하여 Figure 11과 같이 구 글 플레이스토어에서 앱을 검색하여 설치할 수 있게 하였다.

\section{DISCUSSIONS}

본 연구에서는 청각장애 아동의 청각기억 증진을 위해서 6 
Figure 8. Examples of the application's implementing process.

Figure 9. SMS services of the child's performance.

Figure 10. Results of usability testing (Five-point scale with a maximum score of 5).

개의 시나리오로 구성된 앱을 개발하였다. 개발된 앱에는 청각 장애 아동의 흥미를 높이기 위해서 캐릭터, 애니메이션, 효과음 등이 제시되며, 부모가 청각장애 아동의 수행 이력의 저장과 결과 전송을 할 수 있도록 SMS 서비스 기능도 포함되어 있다. 본고에서는 콘텐츠 조사 및 준비 단계, 기획 및 개발 단계, 앱
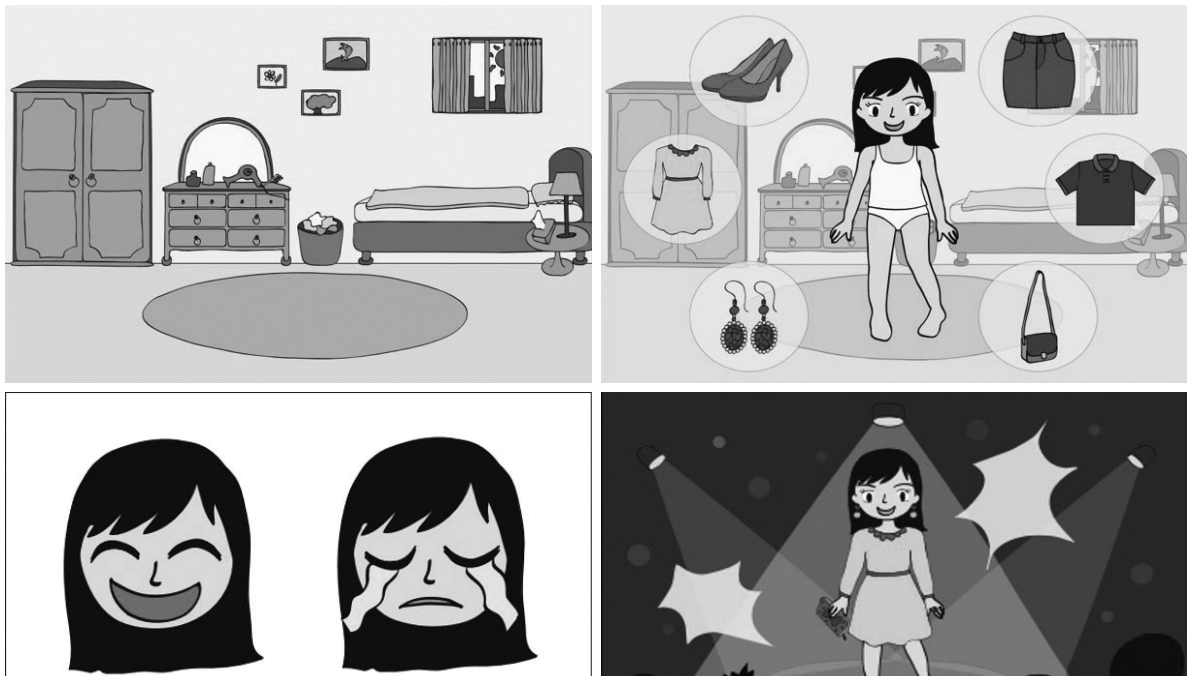

Character's facial expression according to correct/incorrect response
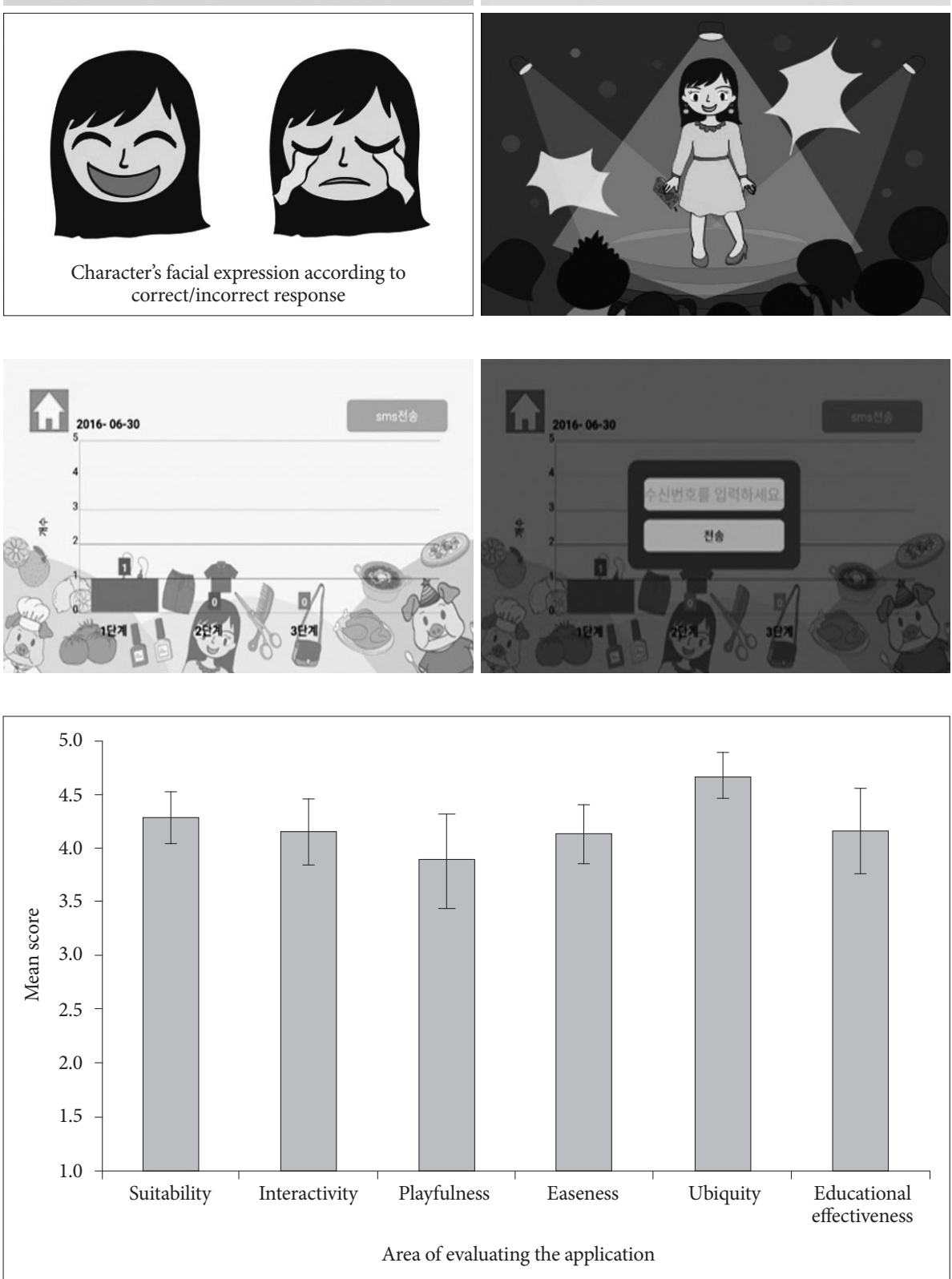

시험판 개발 후의 사용성 평가, 앱의 등록까지의 앱 개발 사례 의 전 과정에 대해서 소개하였다. 본 연구는 청능재활 분야에 서의 모바일 러닝을 위한 앱 개발과 관련하여 다음과 같은 시 사점을 제안하다.

첫째, 청능재활을 위한 앱은 청각장애, 듣기 특성 및 기술 발 


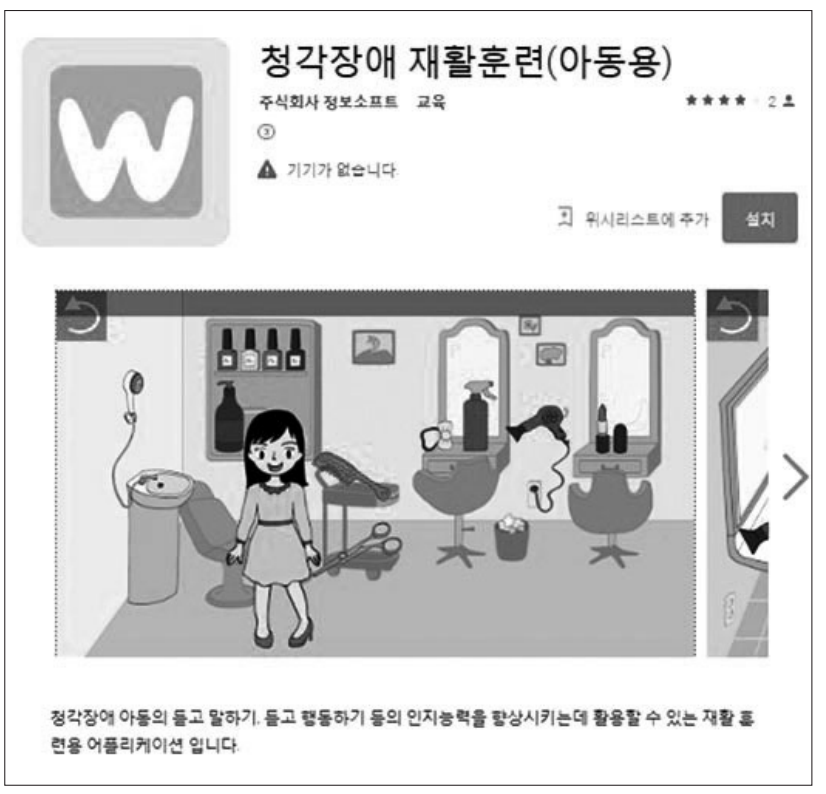

Figure 11. Web page of the application's registration.

달 등과 같은 지식과 경험을 토대로 콘텐츠를 개발하고 전문가 에 의해 내용에 대한 검증이 이루어져야 한다. 현재 전문가와 부모의 모바일 러닝에 대한 관심과 앱 콘텐츠 요구도를 충족시 킬 만큼의 앱 개발이 양적으로 이루어지지 못 하고 있다(Lee, 2016; Lee et al., 2016). McNaughton \& Light(2013)는 전문적 인 교육 및 재활 콘텐츠 없이 장애 아동을 위한 앱이 무분별하 게 개발되어 배포되는 것에 대해 우려하면서, 재활 및 교육 전 문가가 앱 개발 과정에 참여하고 앱에 대해서 평가하는 역할을 해야 한다고 강조하였다. Yoo et al.(2012a)은 앱 콘텐츠가 교육 적절성의 검증 없이 아동에게 노출되고 있는 점에 대해 지적하 면서, 전문가가 콘텐츠를 지속적으로 선별하여 아동에게 적합 한 콘텐츠를 확보해야 한다고 하였다. 청각장애 아동의 듣기 기 술, 말, 언어 발달 등에서 개인 간 차이가 일반 아동보다 큰 것 을 고려한다면, 청각장애 아동에게 적합한 수준별 콘텐츠의 개 발과 검증이 필요하겠다.

둘째, 청각장애 아동이 청능재활 앱을 이용한 학습에 흥미를 느낄 수 있도록 다양한 캐릭터, 음성 및 음향, 다양한 기술 기 법 등을 활용할 필요가 있다. 본 연구의 사용성 평가 결과에서 유희성이 다른 영역(적절성, 상호작용성, 용이성, 편재성, 교육 효과성)에 비해서 낮은 것으로 나타났다. 본 연구에서 개발한 앱이 캐릭터와 애니메이션으로 청각장애 아동에게 앱 활동 중 에 피드백을 제공하고 있지만, 일반 아동의 교육용 앱에 비해서 캐릭터의 정교성과 게임적 요소의 활용이 부족했던 것으로 판 단된다. 즉, 개발한 앱이 교육 효과에 초점을 많이 두고 개발되 어, 유희성과 관련된 캐릭터의 정교성, 게임적 요소가 충분히 반영되지 못했던 것으로 생각된다. 이러한 개발 경험을 토대로,
향후에는 캐릭터 디자이너, 게임 스토리 전문가, 게임 개발자 등의 전문가와 협업을 하여, 교육 효과뿐만 아니라 유희성을 모 두 충족할 수 있는 앱 개발이 필요하겠다. Lee(2012)는 아동용 앱에서는 스마트폰에 탑재된 기능을 최대한 활용할 수 있는 형 태로 인터페이스를 개발해야 아동이 좀 더 직관적인 방식으로 앱 활동에 참여하여 교육효과가 높아질 수 있다고 하였다. 그리 고 Yoo et al.(2012b)은 아동이 동물이 의인화된 형태의 캐릭터 에 대한 선호도가 높으며, 아동의 선호도에 따라서 앱 활동에 몰입하는 정도에 차이가 난다고 언급하였다. 향후 청각장애 아 동의 앱 개발 시에 아동의 반응에 즉각적인 피드백이 가능하도 록 인터페이스를 개발하고, 아동과 캐릭터가 좀 더 적극적으로 상호작용하는 형태의 시나리오와 역동성이 높은 캐릭터의 개 발이 필요하겠다.

셋째, 청각장애 아동을 대상으로 앱을 활용한 모바일 러닝의 효과에 대한 연구를 진행하며, 연구결과물의 형태가 아니라도 전문가 간에 앱에 대한 정보를 공유하기 위한 방안을 모색할 필요가 있다. Fu \& Galvin(2007)과 Nekeva von Mentzer et al. (2014)은 컴퓨터 프로그램을 활용한 중재가 보청기나 인공와우 를 착용한 청각장애 아동의 음운처리, 철자 학습, 읽기 기술 발 달에 긍정적인 영향을 미친다고 보고하였다. 다른 연구(Sweetow \& Sabes, 2006; Zhang et al., 2014)에서도 컴퓨터를 활용 한 중재가 직접 방문하여 비용을 지불하기를 망설이는 청각장 애 성인의 듣기 기술 발달에 긍정적인 효과가 있었다고 보고되 었다. 즉, 선행 연구(Fu \& Galvin, 2007; Nekeva von Mentzer et al., 2014; Sweetow \& Sabes, 2006; Zhang et al., 2014)를 통 해서 전문적인 콘텐츠와 테크놀로지가 결합하여 청각장애 아 동과 성인에게 제공하는 중재가 기존의 치료법과 병행하여 재 활 효과를 더 높일 수 있음을 확인할 수 있었다. 청능재활 분야 에서는 Yu et al.(2014)이 어음인지력 향상을 목적으로 앱을 개 발하였으며, 중도의 감각신경성 난청 성인에게 앱 중재를 실시 하여 긍정적인 중재 효과에 대해서 보고하였다. 테크놀로지와 의 결합이 활발한 보완대체의사소통(Augmentative and Alternative Communication) 분야에서는 Buchholz et al.(2016) 이 언어재활사, 특수교사, 작업치료사, 물리치료사 등의 전문가 간에 의사소통장애 아동 및 성인이 사용할 수 있는 앱, 활용방 법, 앱의 장단점에 대해서 공유하는 온라인 사이트 운영 사례 를 발표한 바 있다. 이러한 전문가의 활동 사례는 모바일 러닝 의 초기 단계인 우리가 어떤 방향으로 청능재활에서 모바일 러 닝을 접근해야 되는지에 대해서 알려주는 바가 있다. 즉, 이는 청능재활 전문가가 앱 개발, 평가뿐만 아니라 기존에 개발된 앱 의 활용방법과 후기의 공유를 통해 비전문가가 무분별하게 앱 을 개발하고 배포하는 것을 예방하고, 보다 나은 앱 개발에 필 요한 정보를 제공하는 역할도 할 필요가 있음을 시사한다. 
Traxler(2007)는 모바일 러닝의 장점으로 학습자의 요구에 따라서 어디서나 학습이 이루어질 수 있고, 학습자의 자기주도 적인 학습을 가능하게 하며, 학습자의 수행에 따른 피드백을 통해서 학습능력 향상을 가져올 수 있다는 점을 언급하였다. Kwon et al.(2012)과 Lim \& Park(2012)도 모바일 기기의 휴대 성, 높은 사용성, 예측 가능성, 앱의 다양성, 비주얼 디스플레 이, 문화 수용성 등이 교육 도구로서의 잠재력을 극대화시킬 수 있다고 강조하면서, 장애 아동, 교사, 부모의 입장에서 다양 한 앱을 개발하고 출시할 필요가 있다고 언급하였다. 이러한 교 육적 효과 외에도, 본 연구의 저자는 모바일 러닝이 청능재활 전문가의 수가 절대적으로 부족한 산간 지역에 거주하는 청각 장애 아동에게도 전문적인 청능재활 콘텐츠를 접할 수 있는 기 회를 제공할 수 있기 때문에, 장애로 인해 더 부각될 수 있는 청 능재활에서의 지역적, 경제적 격차를 줄이는 데 기여할 수 있을 것으로 기대하고 있다. 모바일 기술의 발달을 잘 이용한다면 청 각장애 아동의 학습 몰입도를 향상시키고, 아날로그 미디어로 재현할 수 없는 학습 자료의 개발이 가능하다. Hwang \& So (2016)가 언급한 보편적 설계의 관점에서 청능재활을 위해 개 발된 앱이 다른 장애 아동, 다문화 가정, 말-언어 늦은 아동, 일 반 아동과 같은 폭넓은 대상자에게도 활용될 수도 있을 것이 다. 향후 연구에서는 청각장애 아동의 부모와 전문가에게 함께 사용성 평가를 실시하여 앱에 필요한 기능을 구체적으로 살펴 보고, 앱을 이용한 중재를 청각장애 아동에게 실시하여 청능재 활 분야에서의 모바일 러닝 효과에 대해서 살펴볼 필요가 있 다. 앞으로 전문가의 관심과 노력으로 모바일 기술의 발달이 청 각장애 아동과 그 가족의 일상생활까지 지원하는 긍정적이고 혁신적인 기여를 할 수 있기를 기대해본다.

중심 단어 : 모바일 어플리케이션·청능재활·청각장애·아동 · 청각기억.

\section{Acknowledgments}

본 연구는 중소기업청의 기술혁신개발사업의 일환으로 수행하였 음(C0276689, 청각장애 아동의 의사소통 능력 향상을 위한 언어치 료 어플리케이션 개발).

\section{REFERENCES}

American Speech-Language-Hearing Association (ASHA). (2016, December 7). Cochlear Implants. Retrieved from http://www.asha.org/uploadedFiles/AIS-Cochlear-Implants.pdf\#search=\%cochlear\%22.

Buchholz, M., Müller, I. M., \& Derbring, S. (2016). Apps for Communication: Projects and User Cases. Abstract presented at the International Society for Augmentative and Alternative Communication, Toronto, Canada.

Cheon, S. H. \& Yim, D. S. (2016). The effects of parental education using an utterance-analyzing application on initiation, response, and turn-taking in conversations between children with ASD and their parents. Journal of Speech and Hearing Disorders, 25(3), 87-103.

Choi, E. H. (2000). Study of vocabulary development of Korean children (unpublished master's thesis). Yonsei University, Seoul.

Choi, E. A. (2004). Development of Korean children's vocabulary: 3 to 8 years old children oriented (unpublished master's thesis). Korea Nazarene University, Cheonan.

Cole, E. B. \& Flexer, C. A. (2011). Children with Hearing Loss: Developing Listening and Talking, Birth to Six. (2nd ed.). (pp. 1-16). San Diego, CA: Plural Publishing Inc.

Fu, Q. J. \& Galvin, J. J. 3rd. (2007). Computer-assisted speech training for cochlear implant patients: Feasibility, outcomes, and future directions. Seminars in Hearing, 28(2). http://dx.doi: 10.1055/s-2007-973440.

Hwang, G. W. \& So, H. J. (2016). Developing a mobile application to learn Korean for children with hearing impairment: Human-centered design approach. AAC Research and Practice, 4(1), 101-123.

Hyun, E., Yeon, H., Jang, J., \& Lee, E. (2013). Contents analysis of vocabulary learning game application on smart-phone and tablet PC for young children's language learning. The Journal of the Korea Contents Association, 13(11), 551-561.

Im, H., Song, J. Y., Cho, Y. K., Kim, Y. J., Kim, H. J., \& Kang, Y. J. (2013). The use of smartphone applications in stroke rehabilitation in Korea. Brain and Neurorehabilitation, 6(1), 33-40.

Jang, E. J., Park, Y. S., \& Lim, K. (2012). Research on factors effecting on Learners' satisfaction and purchasing intention of educational applications. The Journal of the Korea Contents Association, 12(8), 471-483.

Jang, Y. J. \& Kim, C. W. (2010). The evolution of smartphone market \& the effect by Android. Communications of the Korean Institute of Information Scientists and Engineers, 28(5), 48-56.

Jeong, P. Y. (2014). Speech-language therapy using apps for a student with cerebral palsy. AAC Research and Practice, 2(1), 97-117.

Jutras, B., Ostroff, D., Roy, D., \& Gagne, J. (2003). Auditory sequential organization ability among children and adults with normal hearing. Contemporary Issues in Communication Science and Disorders, 30, 113-117.

Kim, H. A. (2016, February 21). Domestic smartphone OS market share, Android $\downarrow$, iOS $\uparrow$. E-daily. Retrieved from http://m.news.naver.com/ read.nhn?mode=LSD\&sid1 $=001 \&$ oid= $018 \&$ aid $=0003481800$.

Korean Institute of Korean Language (2012). Development of Korean vocabulary contents (Level 1). Seoul: Korean Institute of Korean Language.

Kwon J. M., Park, E. H., Lim, J. H., \& Lee, Y. Z. (2012). Proposal for mobile application and game for persons with autism. Journal of the Korean Society for Computer Game, 25(1), 31-42.

Lee, M. Y. (2008). Diagnostic therapy for infants with hearing impairment. The 5th Dong-A Hearing Symposium. Busan, Korea.

Lee, S. G. \& Lee, Y. (2016). The effects of auditory intervention using smartphone application on auditory memory in children with cochlear implants. The 30th Korean Academy of Speech-Language Pathology and Audiology Conference, Seoul, Korea.

Lee, W. H. (2012). A practical use of touch interface design for educational applications: focus on smart phone apps for children. Journal of Korea Design Forum, 36, 379-388.

Lee, Y. (2016). Parental current practice and needs in smart device applications for children with cochlear implants. Audiology and Speech Research, 12(4), 269-279.

Lee, Y., Kim, Y. T., \& Park, E. H. (2016). Analysis on current practice and needs based survey of parents and speech-language pathologists for reading intervention with smart device applications. Communication Sciences and Disorders, 21(3), 502-514.

Lee, Y., Lee, S., \& Sung, M. (2015a). Analysis of mobile application trends for speech and language therapy of children with disabilities in Korea. Journal of the Korean Society of Speech Sciences, 7(3), 153-163.

Lee, Y., Lim, S., Choi, Y., \& Moon, B. (2015b). A mobile app (see \& speech) of correcting pronunciation for hearing-impaired persons. The Journal of Korean Association of Computer Education, 18(4), 11-18.

Lim, J. \& Park, E. (2012). Development and research trends of application as the smart education media for ASD. Journal of the Korean Association for Persons with Autism, 12(1), 93-117.

Mang, H. K. (2016, July 26). Twenty-five point of day-to-day activities are 
with smartphones. The Korea Times. Retrieved from http://www.hankookilbo.com/v_print.aspx?id=06546274be9e4bd192a238459ea4ef51.

McNaughton, D. \& Light, J. (2013). The iPad and mobile technology revolution: Benefits and challenges for individuals who require augmentative and alternative communication. Augmentative and Alternative Communication, 29(2), 107-116.

Nakeva von Mentzer, C., Lyxell, B., Sahlén, B., Dahlström, Ö., Lindgren, M., Ors, M., et al. (2014). Computer-assisted reading intervention with a phonics approach for children using cochlear implants or hearing aids. Scandinavian Journal of Psychology, 55(5), 448-455.

Sweetow, R. W. \& Sabes, J. H. (2006). The need for and development of an adaptive listening and communication enhancement $\left(\mathrm{LACE}^{\mathrm{TM}}\right)$ program. Journal of the American Academy of Audiology, 17(8), 538-558.

Traxler, J. (2007). Defining, Discussing and Evaluating Mobile Learning: The moving finger writes and having writ.... The International Review of Research in Open and Distributed Learning, 8(2). http://dx.doi.org/ 10.19173/irrodl.v8i2.346.

Tye-Murray, N. (2009). Foundations of aural rehabilitation: Children, adults, and their family members. (3rd ed.). (pp. 139-182). New York, NY: Delmar Cengage Learning.

Yoo, K. J. (2006). The development of internet contents evaluation criteria for early childhood education. Journal of Early Childhood Education, 26(5), 287-306.

Yoo, K. J., Kim, M. K., \& Kim, E. A. (2012a). An analysis of contents and interactions for the educational application on smart-phone and tablet PC. The Journal of Korea Open Association for Early Childhood Education, 17(1), 169-194.

Yoo, S. I. (2015, March 19). 57.2 million mobile subscribe...70\% are 'smartphones'. The etnews. Retrieved from http://www.etnews.com/20150319 000111.

Yoo, S. Y., Kim, H. K., \& Shin, J. W. (2012b). Analysis of character preference according to expression motive in the educational applications for children: focusing on children aged 3 to 6 learning by using a smart phone. Journal of Digital Design, Korea Digital Design Council, 12(3), 95-104.

Yu, J., Chun, H., Song, C. G., \& Han, W. (2014). Case study of speech perception enhancement in hearing-impaired adult by auditory training program of mobile device. Audiology, 10(2), 158-168.

Zhang, M., Miller, A., \& Campbell, M. M. (2014). Overview of nine computerized, home-based auditory-training programs for adult cochlear implant recipients. Journal of the American Academy of Audiology, 25(4), 405-413. 
APPENDIX $\square$

Usability Testing of Applications

\begin{tabular}{|c|c|c|c|c|c|c|}
\hline & \multirow[b]{2}{*}{ 문 } & \multicolumn{5}{|c|}{ 척도 평가 } \\
\hline & & 전혀 & 그렇지 & 보통 & & 매우 \\
\hline 1 & 앱 활동이 교육적 목적을 지니고 있다. & & & & & \\
\hline 2 & 제시된 그림이 실제 사물 또는 행동을 대표한다. & & & & & \\
\hline 3 & 어휘가 취학 전 아동에게 적절하다. & & & & & \\
\hline 4 & 앱 활동이 아동의 경험과 관련되어 있다. & & & & & \\
\hline 5 & 앱 활동이 난이도 별로 제시되어 있다. & & & & & \\
\hline 6 & 피드백*이 즉각적으로 제공된다. & & & & & \\
\hline 7 & 피드백*이 아동의 학습활동을 유도한다. & & & & & \\
\hline 8 & 피드백*으로 아동의 흥미가 증진된다. & & & & & \\
\hline 9 & 앱 종료 후, 아동의 활동이력(수행력)이 제시되어 있다. & & & & & \\
\hline 10 & 아동의 활동이력을 부모와 전문가 간 공유를 할 수 있다. & & & & & \\
\hline
\end{tabular}

※ 피드백은 아동의 수행에 따라 정오반응을 제공하는 것으로, 예를 들면, 활동 안의 캐릭터가 아동의 수행이 정반응일 때는 웃고 오반응일 때는 울상을 짓는 것을 말한다. 